\title{
CD-340 Functionalized Doxorubicin-Loaded Nanoparticle Induces Apoptosis and Reduces Tumor Volume Along with Drug-Related Cardiotoxicity in Mice [Corrigendum]
}

Mondal L, Mukherjee B, Das K, et al. Int J Nanomedicine. 2019;14:8073-8094.

The authors have advised due to an error at the time of figure assembly, Figure 5 on page 8085 is incorrect. The correct Figure 5 is shown below.
The authors apologize for this error and advise it does not affect the results of the paper. 
A

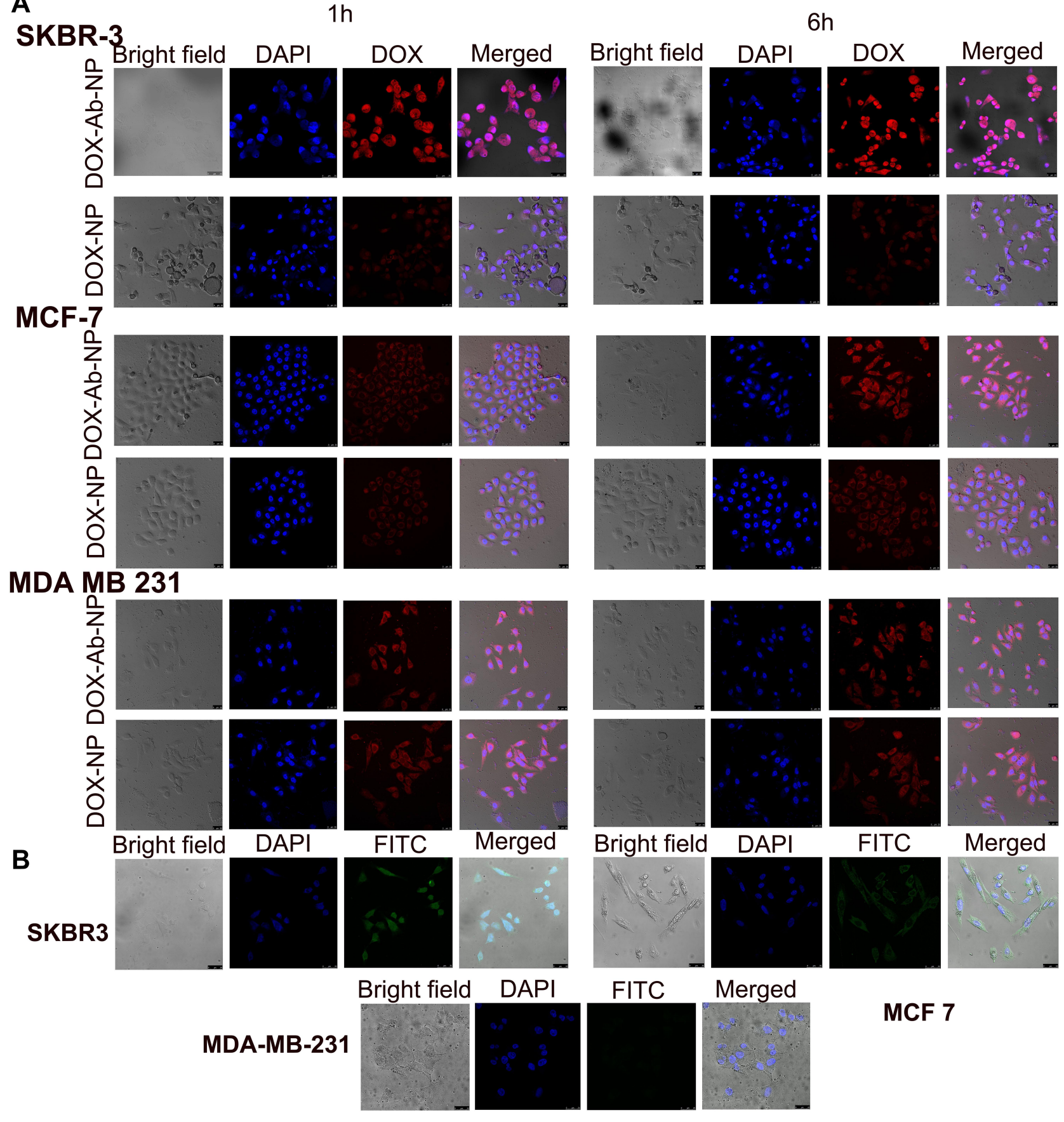

Figure 5 Cellular uptake of antibody conjugated and unconjugated nanoparticles in various cell lines.

Notes: (A) Cellular uptake of DOX-NP and DOX-Ab-NP in SKBR-3, MCF-7, and MDA-MB-23I cells observed by confocal microscopy at I and 6 hrs, respectively. (B) Cellular uptake of antibody-conjugated blank nanoparticles in SKBR-3, MCF-7, and MDA-MB-23I cells observed by confocal microscopy at 6 hrs.

Abbreviations: DOX, doxorubicin; Ab, antibody; NP, nanoparticle. 


\section{Publish your work in this journal}

The International Journal of Nanomedicine is an international, peerreviewed journal focusing on the application of nanotechnology in diagnostics, therapeutics, and drug delivery systems throughout the biomedical field. This journal is indexed on PubMed Central, MedLine, CAS, SciSearch ${ }^{\mathbb{B}}$, Current Contents ${ }^{\mathbb{B}} /$ Clinical Medicine, $^{2}$
Journal Citation Reports/Science Edition, EMBase, Scopus and the Elsevier Bibliographic databases. The manuscript management system is completely online and includes a very quick and fair peer-review system, which is all easy to use. Visit http://www.dovepress.com/ testimonials.php to read real quotes from published authors.

Submit your manuscript here: https://www.dovepress.com/international-journal-of-nanomedicine-journal 